\title{
Analisis Kelayakan Usaha Rumah Potong Hewan di Kabupaten Muaro Jambi: Studi Kasus RPH Cahaya 9
}

\author{
Bambang Saputro, Firmansyah, Fachroerrozi Hoesni \\ Program Studi Magister Ilmu Peternakan Universitas Jambi \\ Correspondence email: bambangsaputrospt@gmail.com
}

\begin{abstract}
Abstrak. Penelitian ini bertujuan untuk mengetahui kelayakan usaha RPH yang merupakan studi kasus RPH Cahaya 9 dari aspek teknis dan aspek finansial serta sensitivitas. Penelitian ini dilaksanakan dari tanggal 05 November sampai 04 Desember 2020. Objek yang diamati dalam penelitian ini adalah Rumah Potong Hewan (RPH) Swasta Cahaya 9 di Kabupaten Muaro Jambi. Data yang diperoleh dari penelitian ini adalah data primer dan data sekunder. Hasil analisis teknis dan teknologi menunjukkan bahwa fasilitas yang ada di Rumah Potong Cahaya 9 hanya 46,88\% memenuhi ketentuan Peraturan Menteri Pertanian Nomor 13/Permentas/OT.140/1/2010 tentang Persyaratan Rumah Potong Hewan dan Unit Penanganan Daging (Meat Cutting Plant) dan SNI 01-6159-1999 tentang rumah pemotongnan hewan. Analisis finansial pada tingkat suku bunga $12 \%$ menunjukkan bahwa Net Present Value > 1 (2.033.681.438), Net Benefit/Cost > 1 ( 3,10) dan Internal Rate of Return > 1 (66,59). Hasil analisis ini menunjukkan bahwa usaha RPH Cahaya 9 secara finansial adalah layak dilanjutkan. Layak secara finansial namun sensitif terhadap perubahan (kenaikkan) modal pembelian ternak. Biaya pembelian ternak potong mencapai $97,10 \%$ dari total biaya operasional. Pada suku bunga $12 \%$ biaya pembelian ternak potong akan menghasilkan $N P V<1$ sebesar $-8.488 .856,574$, Net B/C $<$ 1 sebesar sebesar -7,78 dan IRR sebesar negatif, maka hasil ini mengakibatkan usaha menjadi tidak layak .
\end{abstract}

Kata kunci: Analisis Finansial; Analisis Kelayakan Teknis; Analisis Sensitivitas; Daging; Rumah potong hewan.

Abstract. This study aims to determine the business feasibility of RPH which is a case study of Cahaya 9 slaughterhouse from technical aspects and financial aspects as well as sensitivity. This research was conducted from November $5^{\text {th }}$ to December $4^{\text {th }}$ 2020. The object observed in this study was the Cahaya 9 Private Slaughterhouse (RPH) in Muaro Jambi Regency. The data obtained from this study are primary data and secondary data. The results of technical and technological analysis show that only $46.88 \%$ of the facilities in Cahaya 9 Slaughterhouse comply with the provisions of the Regulation of the Minister of Agriculture Number 13 / Permentas / OT.140 / 1/2010 concerning Requirements for Slaughterhouses and Meat Handling Units. ) and SNI 016159-1999 concerning animal slaughterhouses.Financial analysis at an interest rate of $12 \%$ shows that Net Present Value > 1 (2,033,681,438), Net Benefit / Cost > 1 (3.10) and Internal Rate of Return > 1 (66.59). The results of this analysis indicate that the light 9 RPH business is financially feasible to continue. Financial feasibility but sensitive to changes (increase) in purchasing capital for livestock. The cost of purchasing beef cattle reaches $97.10 \%$ of the total operating costs. At an interest rate of $12 \%$, the cost of purchasing beef cattle will result in an NPV $<1$ of $-8,488,856,574$, Net B / C $<1$ of -7.78 and an IRR of negative, which results in the business being unfit.

Keywords : Financial Analysis; Technical Feasibility Analysis; Sensitivity Analysis; Meat; Slaughterhouse.

\section{Pendahuluan}

Daging merupakan salah satu pangan sumber protein hewani yang disukai oleh masyarakat. Tingginya permintaan daging segar membuka peluang bagi pelaku usaha daging untuk melakukan pemotongan baik di rumah potong hewan ataupun di tempat-tempat pemotongan hewan. Amanat Undang-Undang Nomor 41 Tahun 2014 tentang Perubahan atas Undang-Undang Nomor 18 Tahun 2009 Tentang Peternakan dan Kesehatan Hewan bahwa ternak yang dagingnya diedarkan untuk masyarakat umum harus dipotong di Rumah Potong Hewan (RPH). Hal ini mengharuskan setiap daerah wajib memiliki RPH baik yang dibangun oleh pemerintah daerah ataupun oleh pihak swasta. Ketentuan mengenai RPH diatur dalam Peraturan Menteri Pertanian RI Nomer 13/Permentan.OT.140/1/2010 tentang Persyaratan Rumah Potong Hewan Ruminansia dan Unit Penanganan Daging (Meat Cutting Plan) dan ditetapkannya Standar Nasional Indonesia (SNI) 01-6159-1999 tentang Rumah Potong Hewan. RPH Cahaya 9.adalah milik swasta berlokasi di Kecamatan Sungai Gelam Kabupaten Muaro Jambi Provinsi Jambi. Jumlah pemotongan per hari di RPH Cahaya 9 dipengaruhi oleh kondisi penjualan daging di pasar tradisional di Kota Jambi. Kondisi pasar yang fluktuatif ini mempengaruhi pendapatan finansial sehingga kinerja RPH menjadi rendah. Oleh karena itu sangat diperlukan penelitian yang mendalam tentang kelayakan Rumah Pemotongan Hewan CAHAYA 9 di Kecamatan Sungai Gelam Kabupaten Muaro Jambi.

\section{Metode}

Penelitian ini adalah penelitian studi kasus RPH cahaya 9. Menurut Hodgetts dan Stolte (2012), penelitian studi kasus menyelidiki suatu peristiwa, situasi, atau kondisi sosial tertentu dan untuk memberikan wawasan dalam proses yang menjelaskan bagaimana peristiwa atau situasi tertentu terjadi. Penelitian studi kasus sering digambarkan 
sebagai metodologi yang fleksibel, menantang dan paling umum digunakan dalam penelitian ilmu sosial. Namun demikian dukungan dan perhatian terhadap studi kasus paling sedikit karena tidak adanya protokol yang terdefinisi dengan baik (Cope, 2015), tidak ada standardisasi atau formula bagaimana melakukan penelitian studi kasus (Yin, 2002). Data yang dikumpulkan adalah data primer yang diperoleh langsung baik melalui observasi maupun melalui wawancara. Menurut Hasan (2002) data primer ialah data yang diperoleh atau dikumpulkan langsung di lapangan oleh orang yang melakukan penelitian atau yang bersangkutan yang memerlukannya. Sedangkan data sekunder merupakan data yang didapat dari orang lain atau berbentuk dokomen, media massa, dan literatur.

\section{Analisis Kelayakan Teknis}

Menganalisis kelayakan aspek teknis berdasarkan Peraturan Menteri Pertanian Nomor 13/Permentan/OT.140/1/2010 yang meliputi : Persyaratan Lokasi, Persyaratan Sarana Pendukung, Persyaratan Tata Letak, Desain, dan Konstruksi serta Peralatan.

\section{Analisis Kelayakan Finansial}

Dalam rangka mencari suatu ukuran menyeluruh tentang baik tidaknya RPH digunakan berbagai macam indeks yang disebut Investment Criteria. Setiap indeks itu menggunakan present value yang telah di-discount dari arus-arus benefit dan cost selama umur suatu proyek, yaitu :

a) Net Present Value (NPV), NVP adalah selisih antara present value dari benefit dan present value dari cost dengan rumusan sebagi berikut :

$$
N P V=\sum_{t=1}^{n} \frac{B_{t}-C_{t}}{(1+t)^{t}}
$$

Ket : $\mathrm{B}_{\mathrm{t}}$ : Benefit sosial bruto sehubungan dengan RPH Cahaya 9 pada tahun $\mathrm{t}$; $\mathrm{C}_{\mathrm{t}}$ : Cost sosial bruto sehubungan dengan RPH Cahaya 9 tahun t; n: Umur ekonomis dari RPH Cahaya 9; Social opportunity cost of capital

Keputusan yang diambil adalah :

Jika NPV $\geq 0$ maka RPH Cahaya 9 adalah layak

Jika NPV $=0$ maka RPH Cahaya 9 mengembalikan persis sama social opportunity cost of capital.

Jika NPV < 0 maka RPH Cahaya 9 ditolak.

b) Internal Rate of Return (IRR), IRR suatu proyek merupakan suatu discount rate yang menyamakan present value gross benefit dengan present value cost sepanjang umur proyek. IRR merupakan discount rate i yang membuat Net Present Value sama dengan nol.

$$
I R R=i^{\prime}+\frac{N P V^{\prime}}{N P V^{\prime}-N P V^{\prime \prime}}\left(i^{\prime \prime}-i^{\prime}\right)
$$

Ket : NPV': Net Present Value percobaan pertama; NPV": Net Present Value percobaan kedua; i' : Discount Rate percobaan pertama; i": Discount Rate percobaan kedua

Keputusan yang diambil adalah sebagai berikut :

Jika IRR = i maka NPV = 0, RPH Cahaya 9 mengembalikan persis sama social opportunity cost of capital

Jika IRR < i maka NPV <0, RPH Cahaya 9 adalah ditolak

Jika IRR $\geq$ i maka NPV $\geq 0$, RPH Cahaya 9 adalah dilanjutkan

c) Net Benefit-Cost Ratio (Net B/C)

$$
\operatorname{Net} B / C=\frac{\sum_{t=1}^{n} \frac{B_{t}-C_{t}}{(1+i)^{t}}}{\sum_{t=1}^{n} \frac{C_{t}-B_{t}}{(1+i)^{t}}}
$$

Keputusan yang diambil adalah:

Jika Net B/C > 1 maka RPH Cahaya 9 adalah dilanjutkan

Jika Net B/C $<1$ maka RPH Cahaya 9 adalah ditolak 


\section{Analisis Sensitivitas}

Analisis sensitivitas ini bertujuan untuk melihat bagaimana kelayakan RPH Cahaya 9 jika ada suatu perubahan dalam dasar perhitungan biaya atau benefit. Dalam analisis sensitivitas setiap kemungkinan harus dicoba.

\section{Hasil \\ Rumah Potong Hewan Cahaya 9}

Rumah potong hewan Cahaya 9 adalah milik swasta di Kecamatan Sungai Gelam Kabupaten Muaro Jambi. RPH ini berdiri pada awal tahun 2015 dengan melayani ternak dari petani. Pada tahun 2018 RPH mampu menyediakan ternak potong berupa kerbau yang berasal dari perusahaan. Prospek pasar potensial untuk output dari RPH sangat baik karena berdekatan dengan Wilayah Kota Jambi yang merupakan daerah pemasaran. Kebutuhan akan ternak dan daging sapi untuk konsumsi masih sangat tinggi. Konsumsi daging ternak besar di Kota Jambi yang dilaporkan oleh Dinas Pertanian dan Ketahanan Pangan Kota Jambi selama periode 5 tahun terkahir ini (tahun 2015 sampai tahun 2019) terlihat pada Tabel 1.

Tabel 1.

Data Konsumsi Daging Ternak Besar di Kota Jambi Tahun 2015-2019

\begin{tabular}{llllrr}
\hline \multirow{2}{*}{ Jenis Ternak } & \multicolumn{5}{c}{ Tahun } \\
\cline { 2 - 5 } & 2015 & 2016 & 2017 & \multicolumn{1}{c}{2018} \\
\hline Kerbau $(\mathrm{kg})$ & 310.551 & 265.985 & 203.842 & 464.557 & 602.130 \\
Sapi $(\mathrm{kg})$ & 910.728 & 575.387 & 581.495 & 543.184 & 345.827 \\
Total & 1.221 .279 & 841.372 & 785.337 & 1.007 .741 & 947.957 \\
\hline
\end{tabular}

Sumber : Statistik Peternakan Dinas Pertanian dan Ketahanan Pangan Kota Jambi, 2020

Tingginya konsumsi daging oleh masyarakat Kota Jambi belum dapat diimbangi oleh kemampuan Rumah Potong Hewan Kota Jambi. Jumlah daging yang dihasilkan dari Rumah Potong Hewan Kota Jambi belum dapat memenuhi kebutuhan masyarakat Kota Jambi. Berdasarkan laporan Statistik Peternakan Dinas Pertanian dan Ketahanan Pangan Kota Jambi selama periode 5 tahun terakhir (tahun 2015 sampai tahun 2019), maka dapat diketahui kekurangan jumlah daging ternak besar di Kota Jambi seperti terlihat pada Tabel.2.

Tabel 2.

Data Ketersediaan Daging di Kota Jambi Tahun 2015-2019

\begin{tabular}{lrrrrr}
\hline \multirow{2}{*}{ Uraian } & \multicolumn{5}{c}{ Tahun } \\
\cline { 2 - 6 } & 2015 & 2016 & 2017 & 2018 & 2019 \\
\hline Konsumsi (kg) & 1.221 .279 & 841.372 & 785.337 & 1.007 .741 & 947.957 \\
Kemampuan RPH (kg) & 767.557 & 420.439 & 725.764 & 455.367 & 446.900 \\
Kekurangan (kg) & 453.722 & 420.933 & 58.473 & 329.970 & 501.057 \\
\hline
\end{tabular}

Sumber : Statistik Peternakan Dinas Pertanian dan Ketahanan Pangan Kota Jambi Tahun 2015-2019

Kebutuhan daging semakin lama akan semakin meningkat sejalan dengan pertambahan penduduk di Kota Jambi. Tenaga kerja RPH Cahaya 9 berasal dari orang-orang yang telah dikenal dan informasi karyawan. Tenaga kerja tersebut umumnya sudah memiliki pengalaman menjadi pekerja rumah potong hewan. Pemberian kompensasi berupa upah kerja hanya pada tenaga dokter hewan, administrasi dan pemelihara ternak. Tenaga kerja juru sembelih dan juru tetel menerima upah dari hasil pelaksanaan pemotongan ternak yang dibayar oleh pembeli ternak. Menurut Panggabean (2004), kompensasi dapat diartikan sebagai setiap bentuk penghargaan yang diberikan kepada karyawan sebagai balas jasa atas kontribusi yang mereka berikan kepada organisasi. Bentuk-bentuk kompensasi bisa terbagi menjadi gaji, upah, insentif kerja dan fringe benefit. Kebijakan kompensasi bisa dipengaruhi oleh faktor pemerintah, penawaran bersama antara perusahaan dan karyawan, standar biaya hidup karyawan dan kemampuan membayar karyawan.

\section{Kelayakan Teknis dan Teknologi \\ Persyaratan Lokasi}

Rumah potong hewan Cahaya 9 berada di tengah area pertanian. Berdasarkan Peraturan Daerah Kabupaten Muaro Jambi Nomor 02 Tahun 2014 Tentang Rencana Tata Ruang Wilayah Kabupaten Muaro Jambi Tahun 20142034 bahwa Kecamatan Sungai Gelam diperuntukan sebagai kawasan pertanian lahan basah bukan irigasi. Hal ini sesuai dengan Permentan Nomor 13/Permentan/OT.140/1/2010 yang mensyaratkan rumah potong hewan harus di daerah yang diperuntukkan sebagai area agribisnis. Luas lahan untuk pengembangan RPH adalah 1 (satu) hektar sehingga masih sangat memungkinkan untuk dilakukan pengembangan. Lokasi sekitar RPH adalah lahan pertanian 
dan jauh dari pemukiman penduduk. Letak RPH lebih tinggi dari daerah sekitarnya sehingga kemungkinan terjadinya banjir sangat kecil. Air yang digunakan dalam memenuhi kebutuhan untuk pelaksanaan pemotongan dan kebersihan di RPH berasal dar air sumur bor. Ketersediaan air sangat memadai dan memiliki bak penampungan berkapasitas 1000 liter. Rumah Potong Hewan Cahaya 9 dapat memenuhi seluruh persyaratan lokasi berdasarkan Peraturan Menteri Pertanian Nomor 13/Permentan/OT.140/1/2010.

\section{Persyaratan Sarana Pendukung}

Sarana dan prasarana pendukung RPH dilengkapi dengan sumber listrik dari PLN yang mampu menggerakan restrening box dan memberikan penerangan sehinga pekerja dapat melihat dengan baik. Genset juga disiapkan dalam rangka mengantisipasi jika sumber listrik PLN mati sehingga pekerjaan dapat berjalan dengan baik. Limbah yang dihasilkan oleh RPH belum dikelola lebih lanjut dan tidak dilakukan pemeriksaan sesuai dengan Peraturan Menteri Lingkungan Hidup RI Nomor 5 Tahun 2014 tentang Baku Mutu Air Limbah. Rumah Potong Hewan Cahaya 9 dapat memenuhi 2 (dua) persyaratan sarana pendukung dari 3 (tiga) persyaratan berdasarkan Peraturan Menteri Pertanian Nomor 13/Permentan/OT.140/1/2010.

\section{Persyaratan Tata Letak, Desain dan Konstruksi}

Rumah Potong Hewan Cahaya 9 hanya memenuhi 3 (tiga) dari 9 (sembilan) persyaratan tata letak, desain dan konstruksi berdasarkan Peraturan Menteri Pertanian Nomor 13/Permentan/OT.140/1/2010. Bangunan utama RPH dibangun dengan desain satu ruangan tanpa pemisahan ruang kotor dan ruang bersih sehingga proses pekerjaan dari awal hingga akhir pada ruang yang sama. Operasional ini akan menyebakan terjadinya kontaminasi karena kulit, cairan rumen, darah dan pekerja dengan pakaiannya merupakan sumber kontamisasi bagi karkas sehingga karkas yang dihasilakn dan dipasarkan menjadi tidak aman dan tidak sehat untuk dikonsumsi (Herenda et al, 2007). Kandang penampungan/ kandang istirahat hewan RPH langsung terhubung dari area penurunan hewan. Kesejahteraan ternak terpenuhi karena ternak dapat istirahat, minum dan makan dengan baik. Menurut Riaz dan Chaudry (2004) salah satu syarat pemotongan dan produksi daging halal adalah menampung hewan dalam kondisi yang manusiawi. Tempat penampungan hewan harus tersedia air minum, restrain dilakukan menurut cara yang dianjurkan untuk menghasilkan produk halal yaitu hewan tidak boleh stres. RPH tidak di lengkapi dengan kandang isolasi yang digunakan agar hewan yang sakit dan diduga sakit dapat dilakukan observasi dan pengobatan. Tercampurnya hewan sehat dan sakit dalam satu kandang akan menyebabkan terinfeksinya hewan sehat, sehingga menyebabkan hewan sakit ikut terpotong dan daging yang dihasilkan menjadi tidak sehat, tidak halal, tidak utuh dan tidak aman (Riaz dan Chaudry, 2004).

\section{Peralatan}

Kondisi peralatan yang digunakan RPH hanya terpenuhi 3 (tiga) persyaratan dari 13 (tiga belas) persyaratan berdasarkan permentan Nomor 13/Permentan/OT.140/1/2010. Peralatan dan permukaan yang kontak dengan daging dan jeroan masih terbuat dari kayu seperti meja yang dijadikan alas pemotongan daging. Peralatan seperti pisau dibawa oleh masing-masing pekerja. Bahkan pelaksanaan pekerjaan kotor dan bersih menggunakan pisau yang sama, sehingga kebersihannya dan kehalalannya tidak dapat dipastikan. Menurut Riaz dan Chaudry 2004) untuk menghasilkan daging yang halal, peralatan yang digunakan dalam proses pemotongan dan pengerjaan karkas harus bersih. Peralatan yang digunakan untuk pekerjaan kotor tidak boleh digunakan juga untuk pekerjaan bersih (BSN, 1999; Rudyanto, 2007) Pelaksanaan pengawasan kesehatan masyarakat veteriner di RPH, dilakukan dokter hewan penanggung jawab di RPH namun tidak selalu hadir dalam setiap pemotongan dan daging juga tidak diberi stempel RPH. Ketidakhadiran dokter hewan juga mengakibatkan proses pemeriksaan antemortem dan postmortem tidak dilakukan. Menurut Gracey (1995) bahwa pemeriksaan antemortem dan postmortem perlu dilakukan untuk mendapatkan daging dengan kualitas sehat. Distribusi daging hasil RPH masih menggunakan kendaran dengan bak terbuka, sehingga kemungkinan kontaminasi terhadap karkas dan daging sangat besar. Menurut Rohyati, dkk. (2007) mengatakan bahwa distribusi karkas dan daging dengan mengunakan sepeda motor dan mobil bak terbuka akan menyebabkan masa simpan daging menjadi pendek atau pembusukan daging dipercepat. 
Bambang Saputro, Firmansyah dan Fachroerrozi Hoesni, Analisis Kelayakan Usaha Rumah Potong Hewan di Kabupaten Muaro Jambi: Studi Kasus RPH Cahaya 9

\section{Kelayakan Keuangan}

Tabel 3.

Kelayakan Finansial Rumah Potong Hewan (RPH) Cahaya 9

\begin{tabular}{|c|c|c|c|c|c|}
\hline Tahun & $\frac{\text { Benefit }}{\text { B }}$ & $\frac{\text { Cost }}{C}$ & $\frac{\text { Net Benefit }}{\text { B- C }}$ & $\frac{\text { DF }}{12 \%}$ & NPV \\
\hline 0 & 0 & 967.230 .000 & -967.230 .000 & 1,0000 & -967.230 .000 \\
\hline 1 & 19.602 .157 .000 & 18.875 .916 .700 & 726.240 .300 & 0,8929 & 648.459 .964 \\
\hline 2 & 19.618.607.000 & 18.920 .616 .700 & 697.990 .300 & 0,7972 & 556.437 .867 \\
\hline 3 & 19.635 .879 .500 & 18.999 .637 .700 & 636.241 .800 & 0,7118 & 452.876 .913 \\
\hline 4 & 19.654 .015 .625 & 19.022 .364 .850 & 631.650 .775 & 0,6355 & 401.414 .068 \\
\hline 5 & 19.673 .058 .556 & 19.556.099.618 & 116.958 .939 & 0,5674 & 66.362 .502 \\
\hline 6 & 19.693 .053 .634 & 19.173.593.359 & 519.460 .275 & 0,5066 & 263.158 .575 \\
\hline 7 & 19.714 .048 .466 & 19.212 .051 .248 & 501.997 .218 & 0,4523 & 227.053 .342 \\
\hline 8 & 19.736.093.039 & 19.287.106.587 & 448.986 .453 & 0,4039 & 181.345 .628 \\
\hline 9 & 19.759.239.841 & 19.399 .355 .553 & 359.884 .288 & 0,3606 & 129.774 .274 \\
\hline 10 & 20.164 .263 .983 & 19.934 .362 .415 & 229.901 .568 & 0,3220 & 74.028 .305 \\
\hline \multirow{3}{*}{\multicolumn{4}{|c|}{ Jumlah }} & NPV & 2.033 .681 .438 \\
\hline & & & & Net $B / C$ & 3,10 \\
\hline & & & & IRR & 66,59 \\
\hline
\end{tabular}

Sumber: data olahan

Berdasarkan hasil analisis diperoleh nilai Net Present Value sebesar Rp. 2.033.681.438,--. Analisis ini bertujuan untuk mengetahui tingkat keuntungan yang diperoleh selama umur ekonomi proyek. Nilai NPV > 0 maka RPH layak karena ada penggunaan yang lebih menguntungkan. Net Benefit/Cost Ratio sebesar 3,10. Analisis ini bertujuan untuk mengetahui berapa besarnya keuntungan dibandingkan dengan pengeluaran selama umur ekonomis proyek. Hasil analisis Nilai Net B/C > 1 maka RPH Cahaya 9 layak. Hasil analisis diperoleh nilai Internal Rate of Return (IRR) sebesar 66,59 \%, maka (RPH) Cahaya 9 layak.

\section{Analisis Sensitivitas}

Biaya pembelian ternak potong yang mencapai 97,10\%, sehingga biaya operasional RPH sangat tergantung pada jumlah ternak potong yang dibeli. Kenaikan biaya pembelian ternak sebesar $12 \%$ dengan asumsi yang lain tetap maka diperoleh hasil sebagi berikut :

Tabel 4.

Skenario Kelayakan Finansial Rumah Potong Hewan (RPH) Cahaya 9

\begin{tabular}{|c|c|c|c|c|c|}
\hline \multirow{2}{*}{ Tahun } & Benefit & Cost & Net Benefit & DF & \multirow{2}{*}{ NPV } \\
\hline & $\mathbf{B}$ & $\mathbf{C}$ & B- C & $12 \%$ & \\
\hline \multirow[t]{2}{*}{0} & 0 & 967.230 .000 & -967.230 .000 & 1.0000 & $-967,230,000$ \\
\hline & 18.648 .913 .150 & 19.785 .003 .035 & -1.136 .089 .885 & 0.8929 & $-1,014,414,658$ \\
\hline 2 & 18.665 .363 .150 & 19.829 .703 .035 & -1.164 .339 .885 & 0.7972 & $-928,211,756$ \\
\hline 3 & 18.682 .635 .650 & 19.908 .724 .035 & -1.226 .088 .385 & 0.7118 & $-872,729,712$ \\
\hline 4 & 18.700 .771 .775 & 19.931 .451 .185 & -1.230 .679 .410 & 0.6355 & $-782,096,765$ \\
\hline 5 & 18.719 .814 .706 & 20.465 .185 .953 & -1.745 .371 .246 & 0.5674 & $-990,323,645$ \\
\hline 6 & 18.739 .809 .784 & 20.082 .679 .694 & -1.342 .869 .910 & 0.5066 & $-680,297,897$ \\
\hline 7 & 18.760 .804 .616 & 20.121.137.583 & -1.360 .332 .967 & 0.4523 & $-615,278,601$ \\
\hline 8 & 18.782 .849 .189 & 20.196.192.922 & -1.413 .343 .732 & 0.4039 & $-570,849,534$ \\
\hline 9 & 18.805 .995 .991 & 20.308 .441 .888 & -1.502 .445 .897 & 0.3606 & $-541,781,990$ \\
\hline \multirow[t]{4}{*}{10} & 19.211 .020 .133 & 20.843 .448 .750 & -1.632 .428 .617 & 0.3220 & $-525,642,015$ \\
\hline & & Jumlah & & NPV & $-8,488,856,574$ \\
\hline & & & & Net $B / C$ & $-7,78$ \\
\hline & & & & IRR & - \\
\hline
\end{tabular}

Sumber: data olahan

Hasil analisis diperoleh Net Present Value (NPV) yaitu sebesar Rp.-8,488,856,574. NPV adalah selisih antara present value dari benefit dan present value dari cost maka RPH Cahaya 9 tidak layak karena ada penggunaan lain yang lebih menguntungkan. Nilai Net B/C $<1$ serta nilai IRR sebesar negatif maka RPH Cahaya 9 tidak layak. 
Bambang Saputro, Firmansyah dan Fachroerrozi Hoesni, Analisis Kelayakan Usaha Rumah Potong Hewan di Kabupaten Muaro Jambi: Studi Kasus RPH Cahaya 9

Berdasarkan hasil ini maka dapat dijelaskan bahwa RPH Cahaya 9 sangat sensitif terhadap perubahan (kenaikkan) modal pembelian ternak

\section{Simpulan}

Berdasarkan hasil penelitian dapat disimpulkan bahwa :

1. Fasilitas yang ada di Rumah Potong Hewan (RPH) Cahaya 9 di Kecamatan Sungai Gelam Kabupaten Muaro Jambi memenuhi ketentuan sebesar 46,88\% berdasarkan Peraturan Menteri Pertanian Nomor 13/Permentan/OT.140/1/2010 tentang Persyaratan Rumah Potong Hewan dan Unit Penanganan Daging (Meat Cutting Plant) sehingga belum layak secara teknis dan teknologi, tetapi Rumah Potong Hewan (RPH) Cahaya 9 layak secara finansial.

2. Rumah Potong Hewan (RPH) Cahaya 9 di Kecamatan Sungai Gelam Kabupaten Muaro Jambi layak secara finansial namun sangat sensitif terhadap perubahan (kenaikan) modal pembelian ternak

\section{Daftar Pustaka}

Badan Standardisasi Nasional-BSN, (1999). SNI 01-6159-199. Rumah Pemotongan Hewan.

Cope, D. (2015). Case study research methodology in nursing research. Oncology Nursing, 42(6), 681-882. doi: 10.1188/15.ONF.

Gracey, J. F.(1995). Meat Hygiene. 8th Edition. Bailliere Tindal. London. England.

Hasan, M. I. (2002). Pokok-Pokok Materi Metodologi Penelitian \& Aplikasinya. Jakarta : Ghalia Indonesia

Herenda, D, Chambers P.G, A. Ettriqui P. Seneviratna T. J. P. Da Silva, (2007). Manual on Meat Inspection for developing Countries. Fooad And Agriculture Organization of the United Nation Rome. http://www.meat inspection manual/t0756e00.htm

Hodgetts, D. J., \& Stolte, O. M. E. (2012). Case-based research in community and social pychology: Introduction to the special issue. Journal of Community \& Applied Social Psychology, 22, 379-389.doi: 10.1002/casp.2124 .

Panggabean, M. S. (2004). Manajemen Sumber Daya Manusia. Bogor. Ghalia Indonesia.

Peraturan Daerah Kabupaten Muaro Jambi Nomor 2 Tahun 2014 Tentang Rencana Tata Ruang Wilayah Tahun 20142034.

Peraturan Menteri Pertanian Republik Indonesia Nomor 13/Permentan.OT.140 /1/2010 Tentang Persyaratan Rumah Potong Hewan Ruminansia dan Unit Penanganan Daging (Meat Cutting Plan).

Riaz, M. N. And Chaudry, M. M. (2004). Halal Food Prducton. Halal Production Requirements For Meat Poultry. CRC Press. Boca Raton London New York Washington D. C.

Rudyanto. M.D.(2007) Menciptakan Idul Adha Yang "ASUH”. Bagian Kesehatan Masyarakat Veterirer Fakultas Kedokteran Hewan Universitas Udayana. http://www.New page. 1htm

Statistik Dinas Pertanian dan Ketahanan Pangan Kota Jambi Tahun 2020. Laporan Tahunan.

Undang-undang RI Nomor 41 Tahun 2014 Tentang Perubahan Atas Undang-undang Nomor 18 Tahun 2009 Tentang Peternakan dan Kesehatan Hewan.

Yin, R. K. (2002). Case study research: Design and methods (2rd ed.). Thousand Oaks, CA: Sage 